To effect a measurement, the transmitted beam is first cut off by the insertion of a card at $f_{2}$, the potentiometer adjusted to some chosen reading, and the light adjusted by means of $r$ to give a defnite galranometer deflexion. When the blocking card is removed, any light scattered by the sample in $c$ falls on the second photocel, $p_{\mathbf{3}}$, and causes an opposing deflexion of the galvanometer. The potentiometer is then readjusted to produce a null-point reading, and the degree of this readjustment is a measure of the scattered light and thus of the bacterial density.

The sensitivity is widely variable-absolutely by altering the mistance, $r$ in the lighting circuit, and comparatively by inserting neutral-tint filters in the positions marked $f_{1}$ and $f_{3}$. Presence of a filter in the reflected or transmitted beam will respectively increase or decrease the sensitivity.

Apart from its use in the evaluation of disinfectants, the apparatus Apart for the apparatus affected by (a) the medium, $(c)$ variation in $p \mathrm{H}$ and $(d)$ variation in the size of the the medium

Details of the apparatus and of some of these applications will be published elsewhere.

Cooper Technical Bureau,

N. V. NeEdhay.

Berkhamsted.

Oct. 3 .

${ }^{1}$ Alper, T., and Sterne, M., J. Hyg. Camb., 33, 497 (1933).

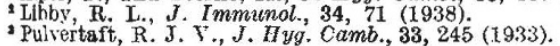

\section{Variation in the Rate of Growth of the Milk-Fish (Chanos chanos)} Chanos chanos (Forskal) is a marine fish which can be easily
acclimatized to fresh water and hence it is recommended for culture in both brackish water and fresh water. (The technique of acclimatizing in both brackish water and fresh water. (The technique of acclimatizing in fresh waters has been perfected at Krusadai.) The flsh, with mullet, in fresh waters has been perfected at Krusad

re reared at the Krusadai marine fish farm. Fingerlings of Chanos measuring 3-4 in. long were collected from shallow creeks near Krusadai and were introduced in June 1944 into three different waters: (1) the marine flsh farm at Krusadai ; (2) brackish water tank at Mandapam Camp; and (3) a freshwater tank, Lakshmana Theertham, at Rameswaram. The tank at Rameswarar is larger and deeper than the otber two; both tanks are spring-fed as well as rain-fed and have no connexion with any other piece of water, whereas the marine flsh farm at Krusadai has a channel connecting it with the sea and consequently the water is affected by tidal action.

At the marine fish farm, the maximum length of milk-fish observed was 10.2 in. in November 1944 , though the average was less than $9.6 \mathrm{in}$. No further growth was noted by the last week of June 1945 In the brackish water tank at Mandapam Camp, fingerlings had by September 1944 grown to an average length of 10.8 in., that is, growth of $7.8 \mathrm{in}$. in three months; one specimen caught in March measured $1 \mathrm{ft} .3 \frac{1}{2}$ in. and in July it was $1 \mathrm{ft} .4 \mathrm{in}$. in length.

In Lakshmana Theertham, a specimen captured in September 194 messured $12 \frac{1}{2}$ in., showing a growth of $9.5 \mathrm{in}$. in three months. On exsmination in November 1944 , the average length was 16.5 in. Specimens of milk-flsh caught in the last week of Jume 1945 had resched $2 \mathrm{ft}$. in length.

Struck by the remarkable variations noticed in the rate of growth of milk-fish belonging to the same stock in three different waters, investigations on the hydrography of the waters were commeaced as early as September 1944. At the marine fish farm at Krusadai the water was of specific gravity $1.0131-1.0279$; surface temperature $27 \cdot 0^{\circ}$ $32 \cdot 2^{\circ} \mathrm{C}$.; hydrogen ion concentration 8.3-8.4. At Mandapam Camp the surface temperature and speciflc gravity of the water were $29 \cdot 4^{\circ}-31 \cdot 0^{\circ} \mathrm{C}$, and $1.009-1 \cdot 0123$ respectively; the $p H$ value was high in June 1945 when it was $8 \cdot 8$. Surface temperature and specific gravity of the Lakshmana Theertham at Rameswaram were $30.5^{\circ}$ $32.5^{\circ} \mathrm{C}$ and $1.000 \mathrm{kshmana}$ Theert

The preliminary study of the plankton of the three waters showed that in the farm at Krusadai the quantity of plankton was poor, that in the farm at Krusadai the quantity of plankton was poor, at Mandapam Camp the plankton is comparatively rich, having a large percentage of copepods; and in Lakshmana Thirtham it is very rich and represented by copepods, daphnids, ostracods and algæ which were found to be the main diet of the fish in the last-mentioned

The large fish examined from all three waters had only traces of gonads, thus indicating the absence of suitable conditions for spawning. The hydrobiological variations of these waters are being studied in greater detail and will be published shortly.

From this work, the rate of growth of Chanos chanos is a maximum in the fresh water, attaining a length of $2 \mathrm{ft}$. in about one year; it

\begin{tabular}{|c|c|c|c|c|}
\hline I.ocality & $\begin{array}{c}\text { No. of } \\
\text { Chanos fry } \\
\text { introduced }\end{array}$ & $\begin{array}{c}\text { Length } \\
\text { when } \\
\text { stocked }\end{array}$ & $\begin{array}{c}\text { Length } \\
\text { after } \\
1 \text { year }\end{array}$ & $\begin{array}{c}\text { Approximate } \\
\text { marketable } \\
\text { value (rupees) }\end{array}$ \\
\hline $\begin{array}{c}\text { Marine Fish } \\
\begin{array}{c}\text { Farm at } \\
\text { Krusadai } \\
\text { Tank at Manda- } \\
\text { pam Camp } \\
\text { Lakshmana } \\
\text { Theertham at } \\
\text { Rameswaram }\end{array}\end{array}$ & 500 & $3 \cdot 4$ in. & $10 \cdot 2$ in. & $0-8-0$ per flsh \\
\hline
\end{tabular}

is less in brackish water, and much less in confined sea water. Growth is rapid in the first few months. The fish grow well in waters rich in zooplankton. The accompanying table gives a comparative idea of value of the fish after a period of one year.

The remarkable growth of the flsh in fresh water and their high market value show their suitability for profltable culture in fresh waters. The Madras Fisheries Department, encouraged by these observations, have supplied 2,500 Chanos fingerlings for the Mandapam Camp tank and about 8,000 for stocking fresh waters in Madras, Madura and Ceylon.

This note is published by permission of the Director of Industries and Commerce, Madras.

$$
\begin{gathered}
\text { Krusadai Biological Station, } \\
\text { Gulf of Mannar, } \\
\text { South India. } \\
\text { Oct. } 31 .
\end{gathered}
$$$$
\text { K. CHIDAMBARAM. }
$$$$
\text { M. MUKUNDAN UNNT. }
$$

\section{REFERENCES :}

Administration reports of Madras Fisheries Department.

Devanesen, D. W., and Chacko, P. I., Proc. Nat. Inst. Sci. Ind., 9. Devanesen, D. W., and Chacko, P. I., Proc. Nat. Inst. Sci. Ind., 9. Adams, Wallace, Montalben, H. R., and Martin, clare, Phil. J. Sci., 47, พo. 1 (1932).

\section{The Ecological Niche}

A SUPERB example illustrating the ecological niche is afforded by the distribution of the plankton copepod Limnocalanus macrurus, a freshwater relict derived from the marine arctic species $L$. Grimaldii. The a nimal has an upper temperature limit of $14^{\circ} \mathrm{C}$., and a lower limit of dissolved oxygen of 4 c.c. $/ 1$. oxygen. In the lowland lakes beyond the arctic region it will therefore during summer stagnation live between the upper waters which are too warm and the lower waters which are too depleted of oxygen.

In the lake Steinsfjord near Oslo a combination of net hauls and the use of a $20 \mathrm{l}$. water-bottle gave the vertical distribution illustrated by the diagram.

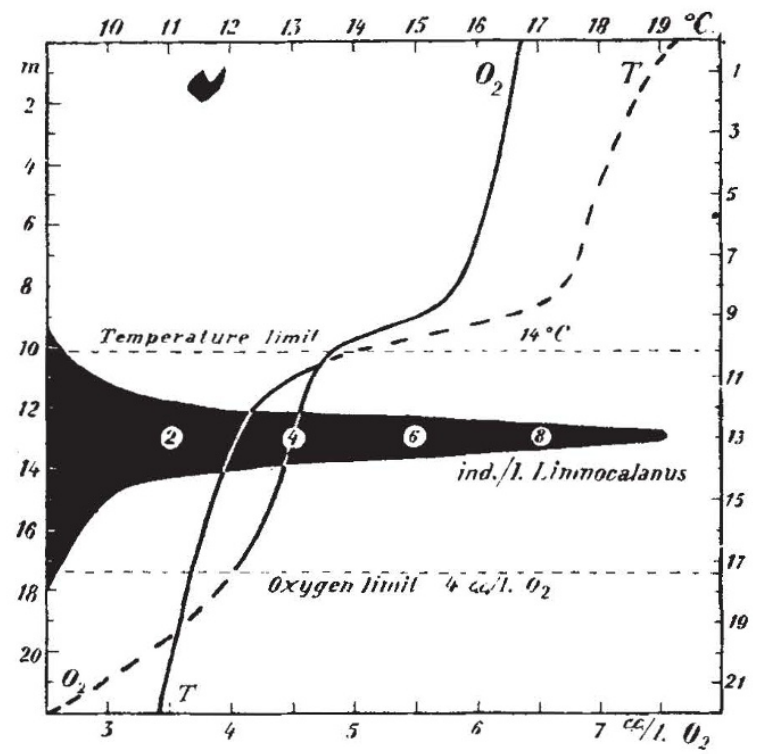

The relative optimum in the circumstances is evidently at about $12^{\circ} \mathrm{C}$. and 4.5 c.c./1. oxygen, but the massing of the animals at the depth of $13 \mathrm{~m}$. may also be due to their grazing on dead plankton as near the thermocline as possible.

Limnocalanus thus may be said to live hetween the devil and the deep sea'.

$$
\begin{gathered}
\text { Department of Limnology, } \\
\text { University, Blindern, } \\
\text { Oslo. } \\
\text { Sept. } 27 .
\end{gathered}
$$

Potato 'Bolters' : an Explanation Based on Photoperiodism

ATTEMPTS to solve the problem of the 'bolter' condition in domestic potato varieties have appeared from time to time in these columns. Thomas ${ }^{1}$, for example, demonstrated that bolters differ from norma plants by the presence of a small supernumerary chromosome, though Carson and Howard ${ }^{2}$ have found no differences between 'bolter' and normal in this respect. They showed, however, that the 'bolter' condition could be transmitted to its progeny when crossed with

When working on the effect of differing lengths of day on South American potatoes in $1943^{3}$, I was struck by the apparent similarity 